\title{
THE PRODUCTION IN VITRO IN THE NORMAL BRAIN OF STRUCTURES SIMULATING CERTAIN FORMS OF NEGRI BODIES.*
}

Edna Steinhardt, D. W. Poor, and Robert A. Lambert. (From the Research Laboratory of the New York Board of Health and the Department of Pathology, Columbia University, New York City.)

The Negri bodies have been interpreted in two ways, by some observers as protozoa, by the majority, however, as degeneration products of nerve cells. In each of these interpretations the bodies are regarded as specific for rabies. Thus far, neither view has been supported by experimental evidence. The following work was therefore undertaken in the hope that some light might be thrown upon the nature of the bodies in question. Although the results are not entirely conclusive, they lend weight to the view of the degenerative origin of at least some of the smaller forms of Negri bodies.

\section{EXPERIMENTAL WORK.}

The results of the present investigation, which refer, in brief, to certain morphological changes in brain cells under special conditions of incubation, may be conveniently described in three parts, as they relate (I) to the normal brain, (2) to the normal brain inoculated with rabies virus, after the death of the animal, and (3) to the rabid brain.

Technic.-The technic employed consisted simply in an application to our purposes of Harrison's method of cultivating tissues in vitro. Small pieces of the brain of rabbits and guinea-pigs were suspended in hanging drops of blood plasma obtained from the animal from which the brain was to be removed. All portions of the brain were used, but Ammon's horn gave the most satisfactory results in that the ganglion cells in this region developed the most numerous degenerative structures. The culture preparations were incubated at $37.5^{\circ} \mathrm{C}$. for varying lengths of time. In each experiment a number of preparations ( 20 to 50 ) were

* Received for publication September 20 , Igr 2. 
made in order to allow a serial study of the stained cells. An examination was made every two days after incubation was begun, four to ro slides being used each time. Van Gieson's ${ }^{\mathrm{T}}$ method for the rapid diagnosis of rabies, as modified by Williams, ${ }^{2}$ was used for staining the specimens.

In this connection we wish to record our indebtedness to Dr. Van Gieson for his generous assistance in this study.

\section{INCUBATION OF NORMAL BRAIN.}

At the beginning of the present study it was decided to attempt first to produce Negri bodies in vitro by combining outside the body rabies virus and living brain cells. This accomplished, it seemed to us that a study of the character of the bodies could more easily be undertaken. With this end in view an experiment with virus-injected guinea-pig brain, as described in the next division of this paper, was made, a control, however, being made in which an uninjected normal guinea-pig brain was used.

In examining smears from the bits of tissue in the hangingdrop preparations after incubation we were interested to find in the ganglion cells in both series structures practically identical in appearance with certain forms of Negri bodies found in the rabid brain. To exclude the possibility that some error in technic may have been responsible for the findings in the normal control specimens, further experiments were made using pieces of normal brain only. The results of this study will now be briefly described.

Smears made from the pieces of tissue after four to six days' incubation show ganglion cells with well preserved nuclei. The cells are considerably enlarged. If one compares the cells shown in Figs. I and 2 it is seen that the increase in size involves both nucleus and cytoplasm. The nuclei stain lightly by Van Gieson's method. The cytoplasm shows numerous round clear spaces which represent fat droplets in the living cell. It should be noted here that a similar intracellular accumulation of fat has been regularly observed in the cultivation in vitro of the various body tissues. It probably indicates a condition of disturbed metabolism resulting from the changed conditions of life. 
In the cytoplasm of a certain number of the cells there are found small pink-staining bodies, one of which is shown in Fig. 2. These bodies, which we have called "degenerations," are not distinguishable by the usual methods of staining from the small intracellular unstructured Negri bodies observed with great frequency in the rabid guinea-pig brain. Some of the "degenerations" are surrounded by a blue granular ring, such as is seen in typical Negri bodies. In a few instances, structured forms were also found showing a small blue-staining ring in the center (Fig. 3). These "degenerations" closely resemble the small structured forms of Negri bodies in the rabid brain.

In addition to the two intracellular forms, extracellular unstructured forms were also found. Specimens incubated for a longer time (ro to 20 days) did not show any further changes in the character of the structures.

In one experiment in which the brain of a normal puppy was used, the results were unsatisfactory owing to the rapid degeneration of the ganglion cells in the cultures. Whether this was due to faulty technic or to exceptional delicacy of the brain cells of the dog, it will be necessary for further work to determine. Since the Negri bodies found in the brain of a rabid dog have a more complex structure than those in the guinea-pig, the dog's brain should be better suited to studies such as we have undertaken. Further experiments in this direction are contemplated.

\section{INCUBATION OF BRAINS INOCULATED WITH VIRUS.}

Two series of experiments were made using brains from freshly killed animals injected in situ with rabies virus. In both series normal guinea-pig brains were used.

Series 1 .- Street virus; gland extract: The submaxillary glands of a dog dying of rabies (street virus) were extracted under sterile conditions with glycerin. The glycerin was removed by dialysis and the virus concentrated in physiological salt solution by the use of collodion sacs. The virus was injected thoroughly into the substance of the brain by means of a hypodermic syringe. Hanging-drop plasma preparations were made, and incubated as in the preceding set of experiments. 
462 E. Steinhardt, D. W. Poor, and R. A. Lambert

Series 2.-Fixed virus; brain emulsion: The brain of a fixedvirus rabbit was used for making the emulsion. A normal guineapig brain was injected as in Series $I$, and hanging-drop plasma preparations were made.

In both series the results were identical with those obtained with the normal uninoculated brain; that is, the small intracellular unstructured "degenerations," with an occasional structured form, were found after four to six days' incubation.

\section{INCUBATION OF RABID BRAINS.}

Two series of experiments were carried out using street and fixed viruses.

Series 1.-Street virus; guinea-pig's brain: Hanging-drop preparations made with tissue from the brains of guinea-pigs dying of street virus were incubated and examined as in preceding experiments.

Stained smears of the brain before incubation showed mostly the small unstructured Negri bodies usually found in the rabid guinea-pig brain. Upon incubation no development of the forms could be observed, and apparently there was no increase in number. It should be noted here that ganglion cells appear to live in the cultures for to to 20 days or longer. One preparation, 2 I days old, still contained cells that appeared to be living though greatly enlarged. Observed with a $\mathrm{I} / \mathrm{I} 2$ objective and a No. 4 eye piece, one such cell stretched entirely across the field.

Series 2.-Fixed virus; rabbit brain: Small pieces of the brain of a rabbit dying of fixed virus were incubated and stained as in the preceding experiments. In the incubated material small forms with central structure were somewhat more numerous than in the fresh brain. But since no study has as yet been made of the normal rabbit brain incubated in the same manner, we are unable to say how frequently the unstructured "degenerations," such as were observed in the normal guinea-pig brain, would be found under the same experimental conditions.

IV. INOCULATION OF ANIMALS WITH INCUBATED RABID MATERIAL.

Guinea-pigs were inoculated intracerebrally with the incubated preparations of rabid brains as well as with incubated pieces of 


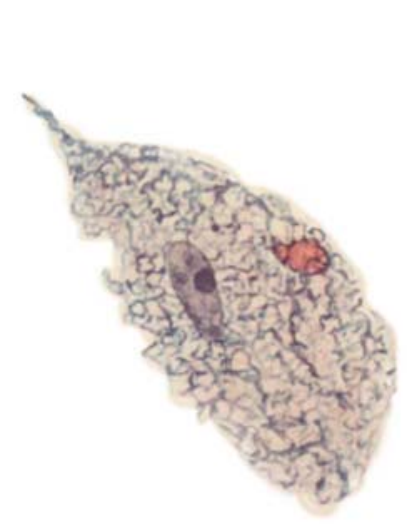

FIG. I.

\section{PLATE 3.}

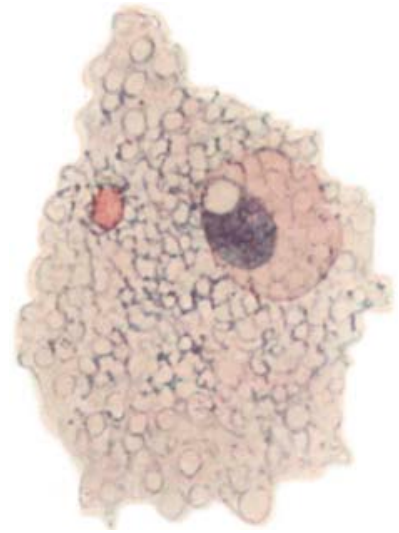

FIG. 2.

FIG. 3. 
normal brains previously injected with virus. The periods of incubation of this material were from six to ro days. There was only one positive result from the inoculations. This was from material from a rabid guinea-pig brain (street virus) incubated for eight days. In this instance, although the virus had lived, there was, in the stained preparations, no evidence that multiplication or development of the Negri bodies had taken place.

SUMMARY.

I. The cells of the normal guinea-pig brain, incubated in blood plasma, showed in their cytoplasm, when stained by Van Gieson's method, small pink-staining bodies surrounded by a blue granular ring, indistinguishable from the unstructured Negri bodies observed with great frequency in the rabid guinea-pig brain.

In a few instances these forms contained a central bluestaining ring or point, and closely resembled some of the smaller structured forms of the Negri body.

2. The normal guinea-pig brain inoculated with rabid material, street or fixed virus, incubated in the same manner, showed the same structures.

3. The brains of guinea-pigs dying of street virus, and rabbits dying of fixed virus, incubated in small fragments, gave no development of the Negri bodies in blood plasma, beyond the small structured and unstructured forms, although in one preparation the ganglion cells appeared to be living at the end of $2 \mathrm{I}$ days' incubation.

\section{EXPLANATION OF PLATE 3.}

FIG. I.-Ganglion cell containing a small unstructured Negri body: from a rabid guinea-pig brain (street virus).

Fig. 2.- Ganglion cell containing a small unstructured "degeneration" from a piece of normal guinea-pig brain incubated in blood plasma six days.

FIG. 3.- Small structured "degeneration" in a ganglion cell from a bit of normal guinea-pig brain incubated eight days.

All preparations were stained according to Van Gieson's method. 